\title{
Inflation Targeting And The Multiplier Accelerator Principle
}

\author{
Christos Karpetis, (E-mail: varelas@uom.gr), Macedonia University, Greece
}

Erotokritos Varelas, (E-mail: karpetis_c@yahoo.gr), Macedonia University, Greece

\begin{abstract}
In this paper we consider a closed economy and using the multiplier - accelerator principle we develop a simple dynamic New Keynesian type model in our effort to determine the time paths of income, actual and expected inflation towards their long - run equilibrium values. The equilibrium values of actual and expected inflation are proved to be affected by government expenditures and the growth rate nominal money supply. Assuming that the Central Bank is interested in stability of real stock of money supply, we specify the rule of determination of the growth rate in nominal money supply. The use of this rule guarantees the equality between inflation and the growth rate of nominal money supply and permits Central Bank to offset the effects of an expansionary fiscal policy on the real stock of money. The theoretic conclusions of our analysis are affirmed by the simulation results presented in the fourth section of our paper.
\end{abstract}

\section{INTRODUCTION}

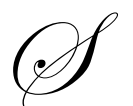

ince the early 1990s a number of countries have adopted inflation targeting in an attempt to reduce inflation. Inflation targeting is not only related with the specification of inflation rate as an objective of economic policy. Moreover, we include (a) the use of monetary policy as the key policy instrument to achieve the target, (b) the operation of monetary policy on behalf of an independent Central Bank and (c) the focus of monetary policy only on inflation rate, while the possible effects of monetary policy on other policy objectives are ignored with the exception of short - term effects. What is suggested in the present article is that inflation targeting is a major policy order closely associated with the New Keynesian Macroeconomics.

The effects of making the monetary factor an integral part of multiplier - accelerator models, like the one created by Hicks (1950), have been examined in a number of articles by Minsky (1957), Wright (1958), Smyth (1963), Laidler (1968), Biederman (1993) and Kaskarelis I. \& Varelas E. (1996). Karpetis C. \& Varelas E. (2004a) investigated the short - run effects of introducing the monetary factor in Samuelson's (1939) multiplier - acceleration model. Moreover, Karpetis C. \& Varelas E. (2004b) developed a New Keynesian type model, in the context of which the contemporaneous movement of real income, actual and expected inflation towards their long-run equilibrium values is determined. Their analysis consist the basis of the analysis presented in this paper.

The present article is divided in five sections. The main features of inflation targeting are presented in the second section of our analysis. In the third section, and moving within the New Keynesian economic theory, we assume that prices are not rigid but relatively flexible, inflationary expectations are adaptive and, in the long-run, income equals full employment level. Under these assumptions, the structural form of the model is set up and a second order system of difference equations is specified and solved with respect to income, actual and expected inflation. Finally, in the fourth section we discuss the transmission mechanism and we present the simulation results of our model, in the context of which we examine the quantitative impact of changes in the level of government expenditures and the growth rate of nominal money supply on the level of several macroeconomic variables.

\section{MAIN FEATURES OF INFLATION TARGETING}

There are certain features forming the key aspects of inflation targeting. Before we embark upon this analysis, it is worth making the comment that different writers put emphasis on different aspects of inflation targeting. The key elements of inflation targeting may be briefly summarized as follows: 
- Inflation targeting is a monetary policy framework whereby public announcement of official inflation targets, or target ranges, is undertaken along with explicit acknowledgement that price stability, meaning low and stable inflation, is monetary policy's primary long - term objective. In this policy framework, inflation targeting is preferred to money supply targeting. This is due to the instability of LM because of the unstable money demand function. King (1997) argues for the superiority of inflation targeting over a money supply rule, in that it results in optimal short - run response to shocks in a way that money - growth targeting does not. Svensson and Woodford (2003) demonstrate the conditions under which inflation targeting might achieve this goal.

- $\quad$ The objectives of the inflation targeting framework are achieved through the principle of constrained discretion [Bernake and Miskin (1997)]. This principle constrains monetary policy to achieve clear long term and sustainable goals, but discretion is allowed to respond sensibly to unanticipated shocks. In this way, inflation targeting serves as a nominal anchor for monetary policy, thereby pinning down precisely the meaning of commitment to price stability. Similarly, monetary policy imposes discipline on the Central Bank within a flexible policy framework. For example, even if monetary policy is used to address short - run stabilization objectives, long - run inflation objectives must not be compromised, thereby imposing consistency and rationality in policy choices. By doing so, monetary policy focuses on public's expectations and provides a reference point to judge short - run policies.

- $\quad$ Monetary policy is considered the main instrument of macroeconomic policy. The view that it is a flexible instrument for achieving medium - term stabilization objectives implies the quick adjustment in response to macroeconomic developments. Indeed, monetary policy is the most direct determinant of inflation in such a degree that in the long - run the inflation rate is the only macroeconomic variable that monetary policy can affect.

- $\quad$ Monetary policy can be used to meet the objective of low inflation rates (which are always desirable, since low and stable rates of inflation are conducive to health growth rates). However, monetary policy should not be operated by politicians but by experts in the form of an independent Central Bank. It is important to distinguish between goal independence and instrument independence [Debelle \& Fisher (1994), Bernake et al (1999)]. The argument is usually couched by the proponents in terms of goal dependence, since it is more democratic for the government to set the goal of price stability, and for the Central Bank to pursue that goal by independent setting of monetary policy's instrument(s). Instrument independence is justified on two grounds: it resolves the problem of time - inconsistency and enables the Central Bank to be forward looking in view of the long and variable lags in monetary policy.

- $\quad$ Monetary policy does not have permanent effects on the level of economic activity. It only has temporary effects, which are serially correlated. Shocks to the level of demand can be met by variations in interest rate to ensure that inflation is not developed. This further implies that a change in monetary stance would have temporary effects, which will persist for a number of periods before they completely dissipate due to price adjustment [Svensson \& Woodford (2003), Hannsgen (2004)].

\section{THE STRUCTURAL FORM OF THE MODEL}

The structural form of the model concerns a closed economy and is described by the following identities and deterministic equations: 


$$
\begin{aligned}
& Y_{t}=C_{t}+I_{t}+G_{t} \\
& C_{t}=c Y_{t-1} \\
& I_{t}=v \Delta C_{t}+b_{2} r_{t-1} \\
& G_{t}=\bar{G} \\
& r_{t}=R \pi_{t}-\pi_{t}^{e}
\end{aligned}
$$

where $\mathrm{Y}_{\mathrm{t}}$ : real gross domestic product, $\mathrm{C}_{\mathrm{t}}$ : real consumption, $\mathrm{I}_{\mathrm{t}}$ : real investments, $\mathrm{G}_{\mathrm{t}}$ : real government expenditure, $\mathrm{r}_{\mathrm{t}}$ : real interest rate, $\mathrm{R}_{\mathrm{t}}$ : nominal interest rate, $\pi_{\mathrm{t}}^{\mathrm{e}}$ : the expected inflation rate, $\mathrm{M}_{\mathrm{t}}^{\mathrm{s}} \& \mathrm{M}_{\mathrm{t}}^{\mathrm{d}}$ : nominal money supply and demand respectively, $\mathrm{P}_{\mathrm{t}}$ : the general price levels, $\mathrm{c} \in(0,1)$ : the marginal propensity to consume, $\quad \mathrm{v}>0$ : the accelerator, $b_{2}<0$ : the interest rate effect on real investments, $G>0$ : the real autonomous government expenditures, $\Delta \mathrm{C}_{\mathrm{t}}=\mathrm{C}_{\mathrm{t}}-\mathrm{C}_{\mathrm{t}-1}, \mathrm{M}_{0}>0 \& \mathrm{P}_{0}>0$ : money stock and the level of prices at $\mathrm{t}=0$ respectively, $\mathrm{m} \in(0,1)$ : the growth rate of nominal money supply, $\pi_{\mathrm{t}}=\left(\mathrm{P}_{\mathrm{t}}-\mathrm{P}_{\mathrm{t}-1}\right) / \mathrm{P}_{\mathrm{t}-1}$ : the inflation rate at period $\mathrm{t}, \mathrm{d}_{1}>0$ : the income effect on real money demand, $\mathrm{d}_{2}<0$ : the interest rate effect on real money demand, $\mathrm{Y}^{*}>0$ : the full employment income and $\lambda>0$ : the speed of adjustment of real income to $\mathrm{Y}^{*}$ and $\gamma \in(0,1)$ : the speed of adjustment of expectations.

Equations (1) to (5) describe the product market. More specifically, according to relation (1), the product market is at equilibrium, when aggregate supply $\left(\mathrm{Y}_{\mathrm{t}}\right)$ equals aggregate demand in real terms. The later is defined as the sum of real consumption $\left(\mathrm{C}_{t}\right)$, real private investments $\left(\mathrm{I}_{\mathrm{t}}\right)$ and real government expenditure $\left(\mathrm{G}_{\mathrm{t}}\right)$. According to equation (2), real consumption at period $t$ is a positive function of previous period's real income. Equation (4) describes real governmental expenditures $\left(G_{t}\right)$ as a fixed positive number. If we followed Samuelson's analysis, we would assume that real investment at period $t\left(\mathrm{I}_{\mathrm{t}}\right)$ is a positive function of the difference of real consumption levelsbetween periods $t$ and $t-1$. In the context of equation (3), this assumption is modified by assuming that real investment function also constitutes a negative function of last periods' real interest rate ${ }^{1}\left(r_{t}\right)$, defined by relation (5) as the difference between nominal interest rate $\left(\mathrm{R}_{\mathrm{t}}\right)$ and expected inflation rate $\left(\pi_{\mathrm{t}}^{\mathrm{e}}\right)$. $\left(\mathrm{M}_{\mathrm{t}}^{\mathrm{s}} / \mathrm{P}_{\mathrm{t}}\right)^{\text {Equations }(6) \text { is defined }}{ }^{2}$ as the describe a Keynesian type money market. According to equation (7), real money supply between the constant growth rate of money supply $(\mathrm{m})$ and inflation $\left(\pi_{\mathrm{t}}\right)$. Equation (8) describes real money demand $\left(\mathrm{M}_{\mathrm{t}}^{\mathrm{d}} / \mathrm{P}_{\mathrm{t}}\right)$ as a positive function of real income $\left(\mathrm{Y}_{\mathrm{t}}\right)$ and a negative function of nominal interest rate $\left(\mathrm{R}_{\mathrm{t}}\right)$. Finally, in the context of identity (6), the money market clears when real money supply equals real money demand.

Equation (9) is the mathematical expression of the expectations augmented Phillips curve and constitutes the functional form of short - run aggregate supply (SAS). The long - run aggregate supply function (LAS) is derived from equation (9) for $\pi_{t}^{\mathrm{e}}=\pi_{\mathrm{t}}$, that is $\mathrm{Y}_{\mathrm{t}}=\mathrm{Y}^{*}$. Finally, equation (10) is the mathematical form of adaptive expectations mechanism and completes the structural form of the model.

\footnotetext{
${ }^{1}$ In macroeconomic models, the real investment in period $t$ is quite frequently assumed to be a negative function of the same period's interest rate. Our assumption that real investment is a function not of $r_{t}$ but of $r_{t-1}$ is based on the time interval that intervenes between taking and realizing an investment decision.

2 Equation (7) is an approximation of the general solution of the following first order difference equation: $\mathrm{M}_{\mathrm{t}}^{\mathrm{s}} / \mathrm{P}_{\mathrm{t}}=(1+\mathrm{m}) \mathrm{M}_{\mathrm{t}-1}^{\mathrm{s}} /\left(1+\pi_{\mathrm{t}}\right) \mathrm{P}_{\mathrm{t}-1}$. For more details regarding the derivation of equation (7) and the mathematics of the model, see Karpetis C. \& Varelas E. (2004b).
} 
The proper combination of equations (1) to (5) leads to the determination of the following relation:

$$
\mathrm{Y}_{\mathrm{t}}-\mathrm{c}(1+\mathrm{v}) \mathrm{Y}_{\mathrm{t}-1}+\mathrm{vc} \mathrm{Y}_{\mathrm{t}-2}=\overline{\mathrm{G}}+\mathrm{b}_{2} \mathrm{R}_{\mathrm{t}-1}-\mathrm{b}_{2} \pi_{\mathrm{t}-1}^{\mathrm{e}}
$$

The satisfaction of (11) ensures that the product market is at equilibrium ${ }^{3}$.

The relation which ensures that money market is at equilibrium can be derived by the combination of equations (6), (7) and (8). The form of this relation has as follows:

$\mathrm{R}_{\mathrm{t}}=\frac{1}{\mathrm{~d}_{2}}\left(\mu_{0}-\mu_{1} \pi_{\mathrm{t}}-\mathrm{d}_{1} \mathrm{Y}_{\mathrm{t}}\right)$

where: $\mu_{0}=\mu_{1}(1+\mathrm{m}) \& \mu_{1}=\mathrm{M}_{0} / \mathrm{P}_{0}$.

Substituting relation (12) in (11) and moving later two periods forward we get the following equation:

$$
\mathrm{Y}_{\mathrm{t}+2}+\mathrm{a}_{1} \mathrm{Y}_{\mathrm{t}+1}+\mathrm{a}_{2} \mathrm{Y}_{\mathrm{t}}+\mathrm{a}_{3} \pi_{\mathrm{t}+1}+\mathrm{b}_{2} \pi_{\mathrm{t}+1}^{\mathrm{e}}=\overline{\mathrm{G}}+\mathrm{a}_{3}(1+\mathrm{m})
$$

where: $\mathrm{a}_{1}=\varphi-\mathrm{c}(1+\mathrm{v}), \mathrm{a}_{2}=\mathrm{vc}>0, \mathrm{a}_{3}=\varphi \mu_{1} / \mathrm{d}_{1}>0 \& \varphi=\mathrm{b}_{2} \mathrm{~d}_{1} / \mathrm{d}_{2}>0$

The above relation is nothing but a second order difference equation with respect to real income and the mathematical expression of the dynamic aggregate demand function $(\mathrm{AD})$.

From the above-cited analysis it is quite clear that relations (9), (10) and (13) consist a linear system of difference equations with constant coefficients, the solution of which gives us the functional form of income time paths $\left(\mathrm{Y}_{\mathrm{t}}\right)$, actual $\left(\pi_{\mathrm{t}}\right)$ and expected inflation $\left(\pi_{\mathrm{t}}^{\mathrm{e}}\right)$. The typical form of this system has as follows:

AD : $\quad Y_{t+2}+a_{1} Y_{t+1}+a_{2} Y_{t}+a_{3} \pi_{t+1}+b_{2} \pi_{t+1}^{e}=\bar{G}+a_{3}(1+m)$

SAS :

$$
\lambda \mathrm{Y}_{\mathrm{t}}-\pi_{\mathrm{t}}+\pi_{\mathrm{t}}^{\mathrm{e}}=\lambda \mathrm{Y}^{*}
$$

AEM :

$$
-\gamma \pi_{t}+\pi_{t+1}^{\mathrm{e}}-(1-\gamma) \pi_{\mathrm{t}}^{\mathrm{e}}=0
$$

Using forward operator ${ }^{4} \mathrm{E}$ we could modify the system $(\mathrm{S}-1)$ in matrix notation into the following form:

$\mathbf{P}(\mathbf{E}) \mathbf{y}_{\mathbf{t}}=\mathbf{H}$

$$
\begin{aligned}
\text { where } & \mathbf{P}(\mathbf{E})=\left[\begin{array}{ccc}
\mathrm{P}_{11}(\mathrm{E}) & \mathrm{P}_{12}(\mathrm{E}) & \mathrm{P}_{13}(\mathrm{E}) \\
\lambda & -1 & 1 \\
0 & -\gamma & \mathrm{P}_{33}(\mathrm{E})
\end{array}\right], \mathbf{y}_{\mathbf{t}}=\left[\begin{array}{c}
\mathrm{Y}_{\mathrm{t}} \\
\pi_{\mathrm{t}} \\
\pi_{\mathrm{t}}^{\mathrm{e}}
\end{array}\right], \mathbf{H}=\left[\begin{array}{c}
\overline{\mathrm{G}}+\mathrm{a}_{3}(1+\mathrm{m}) \\
\lambda \mathrm{Y}^{*} \\
0
\end{array}\right] \\
& \mathrm{P}_{11}(\mathrm{E})=\mathrm{E}^{2}+\mathrm{a}_{1} \mathrm{E}+\mathrm{a}_{2}, \mathrm{P}_{12}(\mathrm{E})=\mathrm{a}_{3} \mathrm{E}, \mathrm{P}_{13}(\mathrm{E})=\mathrm{b}_{2} \mathrm{E} \& \mathrm{P}_{33}(\mathrm{E})=\mathrm{E}-(1-\gamma)
\end{aligned}
$$

\footnotetext{
${ }^{3}$ The derivation of (11) is based on the assumption that aggregate supply is always equal to aggregate demand.

${ }^{4}$ As a result of the multiplication of variable $X_{t}$ with operator $E^{n}$, the variable $X_{t}$ moves forward $n$ periods. In other words, the following properties hold: $E^{n} X_{t}=X_{t+n}$, for $n=0,1,2, \ldots$ and $E^{n} \bar{X}=\bar{X}$, where $\bar{X}$ : a constant.
} 
Assuming that the inverse of the matrix $\mathbf{P}(\mathbf{E})$ exists or, in other words, that the determinant of this matrix is not zero ${ }^{5}$ or $|\mathbf{P}(\mathbf{E})| \neq 0$, we could further modify the system $(\mathrm{S}-2)$ giving it the next form:

$|\mathbf{P}(\mathbf{E})| \mathbf{y}_{\mathbf{t}}=\widetilde{\mathbf{H}}$

where:

$$
\widetilde{\mathbf{H}}=\left[\begin{array}{c}
-\gamma \lambda\left(\mathrm{a}_{3}+\mathrm{b}_{2}\right) \mathrm{Y}^{*} \\
-\gamma \lambda\left[\overline{\mathrm{G}}+\mathrm{a}_{3}(1+\mathrm{m})\right]+\gamma \lambda\left(1+\mathrm{a}_{1}+\mathrm{a}_{2}\right) \mathrm{Y}^{*} \\
-\gamma \lambda\left[\overline{\mathrm{G}}+\mathrm{a}_{3}(1+\mathrm{m})\right]+\gamma \lambda\left(1+\mathrm{a}_{1}+\mathrm{a}_{2}\right) \mathrm{Y}^{*}
\end{array}\right]
$$

The general solution of the system with difference equations $(S-3)$ comes from the summation of a particular solution $\left(\mathbf{y}_{\mathbf{t}}^{\mathbf{p}}\right)$ of $(\mathrm{S}-3)$ with the general solution $\left(\mathbf{y}_{\mathbf{t}}^{\mathbf{c}}\right)^{\text {of }}$ of following homogeneous system of difference equations:

$|\mathbf{P}(\mathbf{E})| \mathbf{y}_{\mathbf{t}}=\mathbf{0}$

The partial solution of the system $(\mathrm{S}-3)$ is nothing but the equilibrium point of the system. Since in the long - run income $(\bar{Y})$ will be equal to its potential level $\left(\mathrm{Y}^{*}\right)$ and inflationary expectations will be fulfilled, in equilibrium the following relations must be satisfied:

$$
\bar{\pi}=\bar{\pi}^{\mathrm{e}}
$$

and

$$
\bar{Y}=\mathrm{Y}^{*}
$$
constants:

Since $\widetilde{\mathbf{H}}$ is a vector of constants, as a partial solution of $(S-3)$ we could try the following vector of $\mathbf{y}_{\mathbf{t}}^{\mathbf{p}}=\left[\begin{array}{lll}\bar{Y} & \bar{\pi} & \bar{\pi}^{\mathrm{e}}\end{array}\right]^{\prime}$

Substituting relations (15) and (17) in $(\mathrm{S}-3)$ and solving for $\overline{\mathrm{Y}}, \bar{\pi} \& \bar{\pi}^{\mathrm{e}}$, we find that:

$$
\left\{\begin{array}{c}
\bar{Y}=Y^{*} \\
\bar{\pi}=\bar{\pi}^{\mathrm{e}}=\frac{\overline{\mathrm{G}}+\mathrm{a}_{3}(1+\mathrm{m})-(1-\mathrm{c}+\varphi) \mathrm{Y}^{*}}{\mathrm{a}_{3}+\mathrm{b}_{2}}
\end{array}\right.
$$

Just like it was expected, equilibrium relations (15) and (16) are satisfied, since the equilibrium value of income equals its potential level $\mathrm{Y}^{*}$ and the inflationary expectations are fulfilled. The equilibrium value of inflation will be equal to growth rate of nominal money supply $(\mathrm{m})$, only if the value of $\mathrm{m}$ is equal to

$$
\mathrm{m}=\frac{1}{\mathrm{~b}_{2}}\left[\overline{\mathrm{G}}+\mathrm{a}_{3}-(1-\mathrm{c}+\varphi) \mathrm{Y}^{*}\right]
$$

\footnotetext{
${ }^{5}$ Given that $|\mathbf{P}(\mathbf{E})|=-\left(E^{3}+e_{1} E^{2}+e_{2} E+e_{3}\right)=\mu_{1}+d_{2}$ this assumption is not fulfilled when $\mu_{1}=-d_{2}$
} 
where $\mathrm{a}_{3}=\frac{\varphi}{\mathrm{d}_{1}} \frac{\mathrm{M}_{0}}{\mathrm{P}_{0}}>0$

The above relation might be considered as a rule of determination of $\mathrm{m}$ by the Central Bank, which ensures the stability of equilibrium value of real stock of money. Given that the initial stock of real money supply $\left(\mathrm{M}_{0} / \mathrm{P}_{0}\right)$ as well as full employment income $\left(\mathrm{Y}^{*}\right)$ are considered to be diachronically constant, the magnitude of $\mathrm{m}$ is affected by variations in $b_{2}, d_{1}, d_{2}, c$, and $\bar{G}$. In order to specify the direction of this effect, we could determine the sign of the partial derivative of $m$ with respect to $b_{2}, d_{1}, d_{2}, c$ and $\bar{G}$. The magnitudes as well as the sign of these partial derivatives are presented in table 1 . With the help of data presented in this table, we will try afterwards to determine the effects of a change in $\bar{G}$ on the growth rate of nominal money supply and the equilibrium values of inflation and real money balances.

Assuming that at time $\mathrm{t}=0$ the system is in equilibrium, the value of $\mathrm{m}$, as this is determined by Central Bank according to relation (19), will be equal to $\bar{\pi}$ and the equilibrium value of real money supply $(\overline{\mathrm{M}} / \overline{\mathrm{P}})$, as this is determined by equation (7) for $\mathrm{m}-\pi_{0}=\mathrm{m}-\bar{\pi}=0$, will be equal to $\mathrm{M}_{0} / \mathrm{P}_{0}$. According to the data presented in table 1 , a permanent increase (decrease) in autonomous real government expenditure by $\mathrm{d} \overline{\mathrm{G}}$ will be followed by a decrease (increase) in the growth rate of nominal money supply on behalf of Central Bank by

$\mathrm{dm}=\frac{\partial \mathrm{m}}{\partial \overline{\mathrm{G}}} \mathrm{d} \overline{\mathrm{G}}=\frac{1}{\mathrm{~b}_{2}} \mathrm{~d} \overline{\mathrm{G}}$

Table 1: The Effect On $m$ By An Infinitesimal Change In $b_{2}, d_{1}, d_{2}, c$ And $\bar{G}$

\begin{tabular}{|l|c|}
\hline \multicolumn{1}{|c|}{ Partial Derivative } & Sign of Effect \\
\hline$\frac{\partial \mathrm{m}}{\partial \mathrm{b}_{2}}=-\frac{\overline{\mathrm{G}}-(1-\mathrm{c}) \mathrm{Y}^{*}}{\mathrm{~b}_{2}^{2}}$ & $\left\{\begin{array}{c}\text { Positive } \\
\text { if } \overline{\mathrm{G}}<(1-\mathrm{c}) \mathrm{Y}^{*}\end{array}\right.$ \\
\hline$\frac{\partial \mathrm{m}}{\partial \mathrm{d}_{1}}=-\frac{\mathrm{Y}^{*}}{\mathrm{~d}_{2}}>0$ & Pogative if $\overline{\mathrm{G}}>(1-\mathrm{c}) \mathrm{Y}^{*}$ \\
\hline$\frac{\partial \mathrm{m}}{\partial \mathrm{d}_{2}}=\frac{\mathrm{d}_{1} \mathrm{Y}^{*}-\mathrm{M}_{0} / \mathrm{P}_{0}}{\mathrm{~d}_{2}^{2}}$ & $\left\{\begin{array}{cc}\text { Positive } & \text { if } \mathrm{d}_{1} \mathrm{Y}^{*}>\mathrm{M}_{0} / \mathrm{P}_{0} \\
\text { Negative } & \text { if } \mathrm{d}_{1} \mathrm{Y}^{*}<\mathrm{M}_{0} / \mathrm{P}_{0}\end{array}\right.$ \\
\hline$\frac{\partial \mathrm{m}}{\partial \mathrm{c}}=\frac{\mathrm{Y}^{*}}{\mathrm{~b}_{2}}<0$ & Negative \\
\hline$\frac{\partial \mathrm{m}}{\partial \overline{\mathrm{G}}}=\frac{1}{\mathrm{~b}_{2}}<0$ & Negative \\
\hline
\end{tabular}

Note: $\mathrm{b}_{2}<0, \mathrm{~d}_{1}>0, \mathrm{~d}_{2}<0,0<\mathrm{c}<1, \mathrm{Y}^{*}>0, \mathrm{M}_{0} / \mathrm{P}_{0}>0 \& \overline{\mathrm{G}}>0$

As a result of the equality $\mathrm{m}=\bar{\pi}=\bar{\pi}^{\mathrm{e}}$, the equilibrium values of actual and expected inflation will also change by $\mathrm{dG} / \mathrm{b}_{2}$ resulting this way in stability of the equilibrium value of real money supply.

On the other hand, if the Central Bank retains the value of $\mathrm{m}$ unchanged, the change of government expenditure by $\mathrm{d} \overline{\mathrm{G}}$ will cause the change of the equilibrium value of inflation by 


$$
\mathrm{d} \bar{\pi}=\frac{\mathrm{d} \overline{\mathrm{G}}}{\mathrm{a}_{3}+\mathrm{b}_{2}}
$$

If $a_{3}+b_{2}>(<) 0$, the increase (decrease) in government expenditure will cause the raise (fall) of the equilibrium value of $\pi$ above (below) $\mathrm{m}$ and the fall (raise) of real stock of money to its new equilibrium value:

$$
\frac{\overline{\mathrm{M}}}{\overline{\mathrm{P}}}=\frac{\mathrm{M}_{0}}{\mathrm{P}_{0}}(1+\mathrm{m}-\bar{\pi})
$$

Central Bank could neutralize the effect of a change in $\bar{G}$ on the equilibrium value of inflation by altering the value of $m$ by

$$
\mathrm{dm}=-\frac{\mathrm{d} \overline{\mathrm{G}}}{\mathrm{a}_{3}}
$$

In this case the increase (decrease) in $\overline{\mathrm{G}}$ will cause the decrease (increase) in m below (above) $\bar{\pi}$ resulting this way in a lower (higher) equilibrium value of real money balances.

A second factor, that affects the equilibrium values of actual and expected inflation, is the controlled by Central Bank growth rate of nominal money supply (m). In order to specify the magnitude of this effect, we will consider all the parameters of relation (18.2) as constants with the exception of the parameter $\mathrm{m}$. Under this assumption, the effect of a change in $\mathrm{m}$ on $\bar{\pi} \& \bar{\pi}^{\mathrm{e}}$ is given by:

$$
\mathrm{d} \bar{\pi}=\mathrm{d} \bar{\pi}^{\mathrm{e}}=\frac{1}{1+\mathrm{d}_{2} / \mu_{1}} \mathrm{dm}
$$

where $\mathrm{d}_{2}<0$ and $\mu_{1}=\mathrm{M}_{0} / \mathrm{P}_{0}>0$.

Since the $\mathrm{d}_{2}$ coefficient describes the effect of a change in nominal interest rate on money demand, its value is expected to be less than $\mu_{1}$, i.e. the initial level of money supply in absolute value. In other words, we expect that $d_{2} /$ $\mu_{1}>-1$ meaning that an increase (decrease) in $\mathrm{m}$ by $\mathrm{dm}$ will result in an increase (decrease) in the equilibrium value of inflation by

$$
\mathrm{dm} /\left(1+\mathrm{d}_{2} / \mu_{1}\right)>\mathrm{dm} \text {. }
$$

The stability of the general system's solution will be achieved, if all the roots of the characteristic equation

$$
\mathrm{P}(\mathrm{k})=\mathrm{k}^{3}+\mathrm{e}_{1} \mathrm{k}^{2}+\mathrm{e}_{2} \mathrm{k}+\mathrm{e}_{3}=0
$$

where $e_{1}=a_{1}-1+a_{3} \lambda, e_{2}=a_{2}-a_{1}-a_{3} \lambda(1-\gamma)+b_{2} \gamma \lambda, e_{3}=-a_{2}$

are less than one in absolute value.

Given that the characteristic equation is of third degree, we will have three characteristic roots $\mathrm{k}_{\mathrm{i}}, \mathrm{i}=1,2,3$. In any case, one of them will be a real number. The other two roots could be either real and distinct, or real and equal or conjugate complex numbers. Using the Routhian theorem of stability ${ }^{6}$, all the characteristic roots will be less than

\footnotetext{
${ }^{6}$ See Kenkel J.L. (1974), Dynamic Linear Economic Models, ch. 7, pp. $174 \sim 184$.
} 
unity in absolute value. In other words, we will have that $-1<\mathrm{k}_{\mathrm{i}}<1$, if for the coefficients $\mathrm{e}_{\mathrm{j}}, \mathrm{j}=1,2,3$ the following inequalities are satisfied ${ }^{7}$ :

$$
\left\{\begin{array}{l}
1+\mathrm{e}_{1}+\mathrm{e}_{2}+\mathrm{e}_{3}>0 \\
3+\mathrm{e}_{1}-\mathrm{e}_{2}-3 \mathrm{e}_{3}>0 \\
3-\mathrm{e}_{1}-\mathrm{e}_{2}+3 \mathrm{e}_{3}>0 \\
1-\mathrm{e}_{1}+\mathrm{e}_{2}-\mathrm{e}_{3}>0 \\
1-\mathrm{e}_{3}^{2}+\mathrm{e}_{1} \mathrm{e}_{3}-\mathrm{e}_{2}>0
\end{array}\right.
$$

Assuming that the value of $\mathrm{m}$ is determined according to (19), the satisfaction of the above cited ${ }^{8}$ stability conditions guarantees that after an exogenous disturbance, i.e. an increase in $\bar{G}$, the system will converge to its new equilibrium point:

$$
\left(\mathrm{Y}^{*}, \bar{\pi}=\mathrm{m}+\mathrm{dm}, \bar{\pi}^{\mathrm{e}}=\mathrm{m}+\mathrm{dm}\right) \text {. }
$$

A question that arises at this point of our analysis has to do with the form of the income time path, actual and expected inflation. In absence of negative characteristic roots, the diachronic movement of the variables will exhibit oscillations, if only two of the characteristic roots are conjugate complex numbers, or equivalently, the following inequality is satisfied:

$\mathrm{D}=\mathrm{K}^{3}+\mathrm{L}^{2}>0$

where $\mathrm{K}=\left(3 \mathrm{e}_{2}-\mathrm{e}_{1}^{2}\right) / 9 \quad \& \quad \mathrm{~L}=\left(9 \mathrm{e}_{1} \mathrm{e}_{2}-27 \mathrm{e}_{3}-2 \mathrm{e}_{1}^{3}\right) / 54$.

Assuming that the characteristic roots are distinct, the general solution of the system $(\mathrm{S}-3)$ will have the following form:

$\mathbf{y}_{\mathbf{t}}=\mathbf{y}_{\mathbf{t}}^{\mathrm{p}}+\mathbf{c}_{\mathbf{1}} \mathrm{k}_{1}^{\mathrm{t}}+\mathbf{c}_{\mathbf{2}} \mathrm{k}_{2}^{\mathrm{t}}+\mathbf{c}_{\mathbf{3}} \mathrm{k}_{3}^{\mathrm{t}}$

where $\mathbf{c}_{\mathbf{i}}=\left[\begin{array}{lll}\mathrm{c}_{1 \mathrm{i}} & \mathrm{c}_{2 \mathrm{i}} & \mathrm{c}_{3 \mathrm{i}}\end{array}\right]^{\prime}, \mathrm{i}=1,2,3$, vectors of constant coefficients, the value of which could be determined with the use of three initial conditions.

\section{THE TRANSMISSION MECHANISM AND THE CONTROL OF INFLATION}

The most interesting aspect of the model for the purposes of this paper is the mechanism whereby inflation is targeted. This is supposed to be placed through equation (13), the dynamic aggregate demand. The component of aggregate demand, which is likely to be the most interest sensitive, is investment expenditure. Higher (lower) real interest rates tend to decrease (increase) aggregate demand, and lower (higher) aggregate demand is assumed to decrease (increase) the rate of inflation. The amount of money in existence and such a monetary policy (perhaps under the impact of monetarism with the clear link between the growth of the stock of money and inflation) has become closely linked with the targeting of inflation rate. In the context of monetary policy's success, this view of inflation,

\footnotetext{
${ }^{7}$ The same stability conditions are derived via the Cohn - Schur stability theorem. For more details see Gandolfo G. (1997), Economic Dynamics - Study Edition, ch. 7, pp. $89 \sim 91$.

${ }^{8}$ Given that $0<\gamma<1,0<\mathrm{c}<1, \varphi>0, \mathrm{~d}_{1}>0, \lambda>0$ and $\mu_{1}>0$, we conclude that the stability condition (26.2) is satisfied for all the acceptable values of the coefficients that appear on the right hand side of the inequality.
} 
namely what is caused by demand factors, raises tow issues. The first is the question how effective monetary policy is influencing aggregate demand and thereby inflation. Second, if inflation is a demand and not a cost phenomenon, then the question arises is whether monetary policy is the most effective way of influencing aggregate demand.

We begin with the transmission mechanism identified in the literature: the interest rate channel; the wealth effect channel; the exchange rate channel; the monetarist channel; the narrow credit channel and the broad credit channel [Arestis and Sawyer (2003)]. The two credit channels, the narrow credit channel and the broad credit channel, are distinct but complementary whereby imperfections in financial markets might affect real magnitudes in the economy. They are concerned with how changes in the financial positions of lenders and borrowers can affect aggregate demand in the economy based on the assumption of credit market frictions. The narrow credit channel focuses on the role of banks as lenders [Bernanke and Blinder (1988), Hall (2001)]. Banks rely heavily on demand deposits subjected to reserve requirements as an important source of funding economic activity. When there is a change in total reserves as a result of changes in monetary policy, bank reserves would be affected, thereby affecting their supply of loans to the private sector. Given that a significant number of firms and households depend on bank lending, ultimately aggregate demand and inflation would be affected. The broad credit channel describes how the financial health of borrowers can affect the supply of finance and ultimately aggregate demand. This channel relies heavily on an imperfect information assumption in terms of the supply of external finance to firms. It is about that lenders charge borrowers a premium to cover monitoring costs; and it is the firm's financial position that determines their eternal finance premium. Thus, low (high) gearing, i.e. high (low) internal finance, implies small (large) external finance premium. Firstly, a policy - induced increase (decrease) in interest rate raises (lowers) the firm's gearing ratio. Secondly, the asset prices play an important role as they determine the value of collateral that bank customers can use to support loan applications. In the presence of information asymmetries, agency costs and other credit market frictions, as well as collateral values are paramount. As the value of the collateral declines, say because of falling asset prices, the borrower premium increases. Consequently, the impact on investment can be significant due to this effect [Bernake, Gertler \& Gilchirst (1999)].

Next, we may take the interest rate and the monetarist channel together. These two channels depend heavily on the assumption made about the degree of substitutability between money and other assets. If this degree is very high between money and financial assets, particularly short - term liquid assets, then changes in the money supply will have significant effects on interest rates. Given some degree of price stickiness, real interest rates and user cost of capital would also be affected. To the extent that the components of aggregate demand are interest rate sensitive, then policy induced changes in interest rates would have a significant impact on the level and pace of economic activity. Financial institutions may decide not to adjust their interest rates in response to a change in the Central Bank interest rate, but rather to apply a form of credit rationing [Stiglitz \& Weiss (1981)]. In this channel, therefore, interest rates provide more information than money supply changes. Monetary policy can be adopted with greater certainty by acting directly to influence and control interest rates than by seeking to control money supply. Monetary authorities have to provide, however, as much monetary base as it takes to achieve their target interest rate. If, by contrast, the degree of substitutability between money and a wide range of assets, including real assets, is high, then the impact of money supply changes would crucially depend on relative price changes. Interest rate changes do not play a special role other than as the one of many relative price changes. Monetary policy should, thus, set the monetary supply and let interest rates become endogenous magnitude [Kuttner \& Mosser (2002)].

The sixth channel of the impact of monetary policy is the exchange rate channel. It links monetary policy to inflation via two routes. The first is via total demand and works through the uncovered interest rate parity condition. The latter relates interest rate differentials to expected exchange rate movements. Policy - induced changes in domestic interest rates relative to foreign interest rates would affect the exchange rate and this would lead to balance of - payment changes. The overall level of aggregate demand would be thereby affected influencing the inflation rate. The second route works through import prices. Changes in the exchange rate affect import prices directly influencing the inflation rate.

In view of this analysis, it is important to examine the quantitative impact of changes in the level of autonomous government expenditures (fiscal policy) and the growth rate of nominal money supply (monetary policy) on the level of several macro-economic magnitudes, given that the Central Bank is interested in the conservation of the real stock of money and knowing that $\mathrm{c}=0.8, \mathrm{v}=0.75, \mathrm{~d}_{1}=0.2, \mathrm{~d}_{2}=-0.5, \mathrm{~b}_{2}=-=0.25, \gamma=0.9, \lambda=40 / 1001$, $\overline{\mathrm{G}}_{0}=10, \mathrm{M}_{0} / \mathrm{P}_{0}=10, \mathrm{~m}_{0}=0.04, \mathrm{Y}^{*}=1501 / 30$. More specifically, assuming that the economy is in equilibrium at periods $t=0, \ldots ., 9$, we will try to determine the effects of an increase at $t=10$ in real government expenditures from 
$\overline{\mathrm{G}}_{0}=10$ to $\overline{\mathrm{G}}_{1}=40001 / 4000$ on the growth rate of nominal money supply and the equilibrium values of real income, real money supply, real consumption and investment, actual and expected inflation.

Since the Central Bank is interested in the conservation of the level of real stock of money, the magnitude of the growth rate of nominal money supply is determined via relation (19). Therefore, the value of $\mathrm{m}$, as well as the equilibrium values of actual and expected inflation, will be decreased at $\mathrm{t}=10$ from $4 \%$ to $3.9 \%$, as a result of the increase in government expenditure. Using now the given values of the parameters $c, v, d_{1}, d_{2}, b_{2}, \mu_{1}, \gamma$ and $\lambda$, we find that $\mathrm{a}_{1}=-1.3, \mathrm{a}_{2}=0.6, \mathrm{a}_{3}=5, \mathrm{e}_{1} \cong-2.101, \mathrm{e}_{2} \cong 1.871$ and $\mathrm{e}_{3} \cong-0.6$. For the values of these parameters the stability conditions, as these are described by relations (26.1) to (26.5), are all satisfied. Moreover, after the substitution of $e_{j}$ coefficients in (27), we find that $D \cong 0.0025>0$. Since $D$ is positive, we reach the conclusion that one of the three characteristic roots will be a real number, while the other two will be conjugate complex. As a result, the magnitude of income, as well as actual and expected inflation, will converge through oscillations to their equilibrium values. This is graphically affirmed ${ }^{9}$ by figures $1 \& 2$.

The use of the short - run aggregate supply function, as this is described by equation (9), implies that actual inflation will exceed (fall short) its expected value whenever real income exceeds (falls short) its equilibrium value. The expected equality between actual and expected inflation on the one hand, real and potential income on the other hand are avowed in the long - run. This is graphically affirmed by figure 3 . The presence, however, of government expenditure and the growth rate of nominal money supply as constituent elements of the equilibrium value of inflation permits the influence of government and Central Bank (inflation targeting) on the long - run value of actual and expected inflation.

In table 2 we present the evolution of the arithmetic magnitude of the main macroeconomic variables of our model. Real income and inflation rise above their initial equilibrium values as a result of simultaneous intervention at period $\mathrm{t}=10$ on behalf of the government and the Central Bank in the goods and money market respectively. Therefore, the real stock of money falls and the real rate of interest rises.

Figure 1: Diachronic evolution of real income

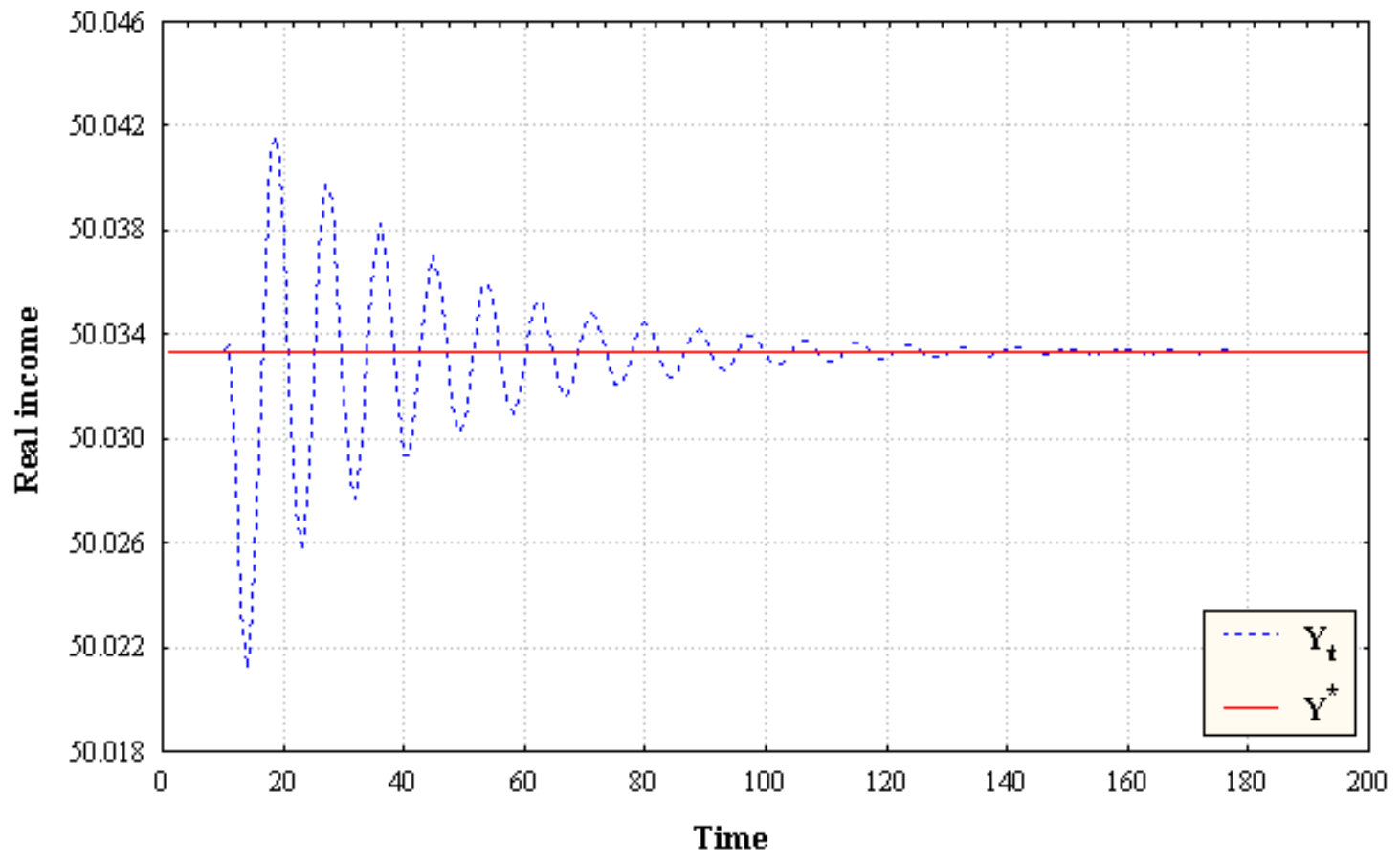

\footnotetext{
${ }^{9}$ In figure 2 it is quite clear that the oscillation of actual inflation comes before the oscillation of expected inflation. This fact is attributed to the use of adaptive expectations as the formation mechanism of expectations.
} 
Figure 2: Diachronic evolution of actual and expected inflation

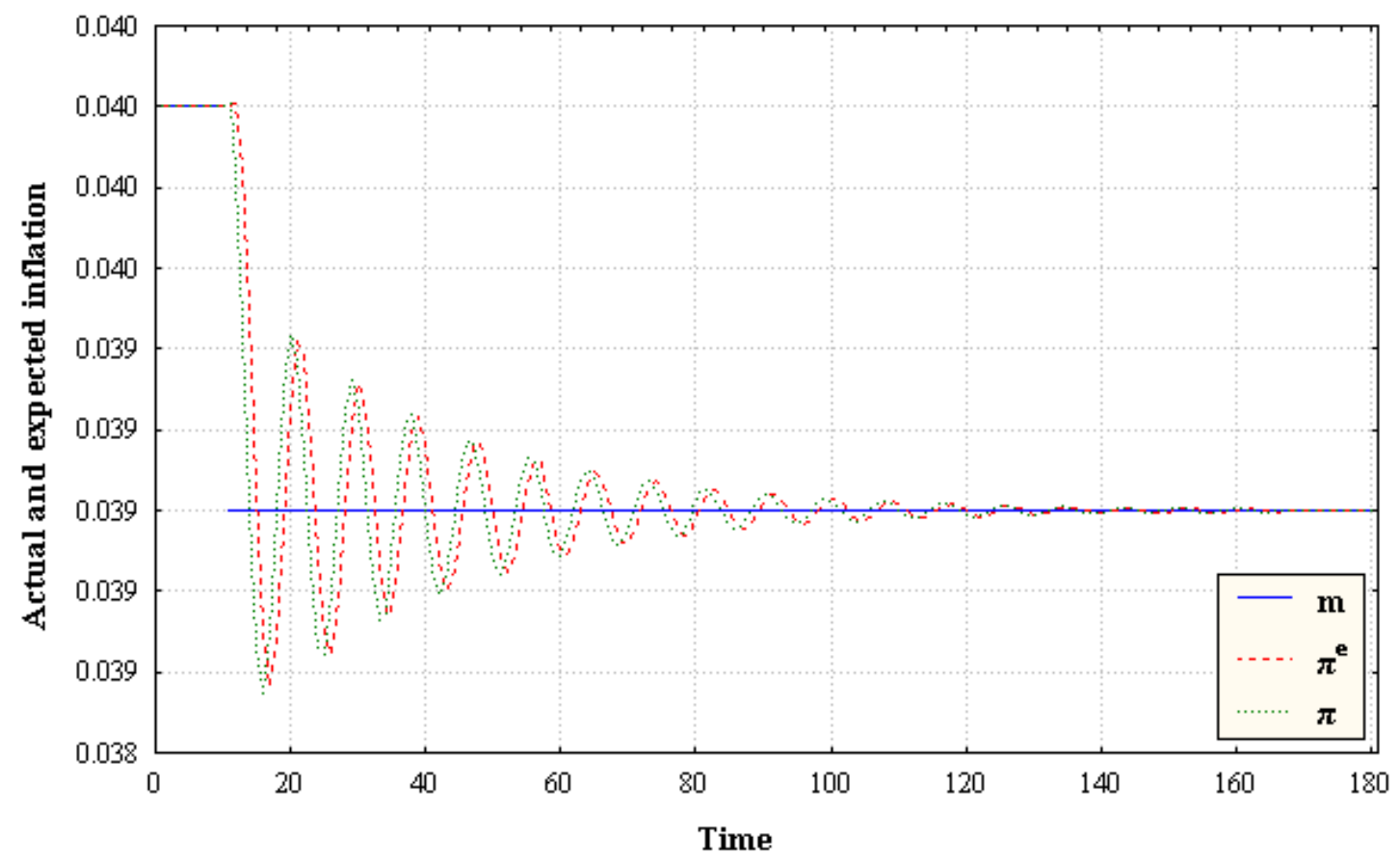

Figure 3: Graphical presentation of differences between actual and potential income \& actual and expected inflation

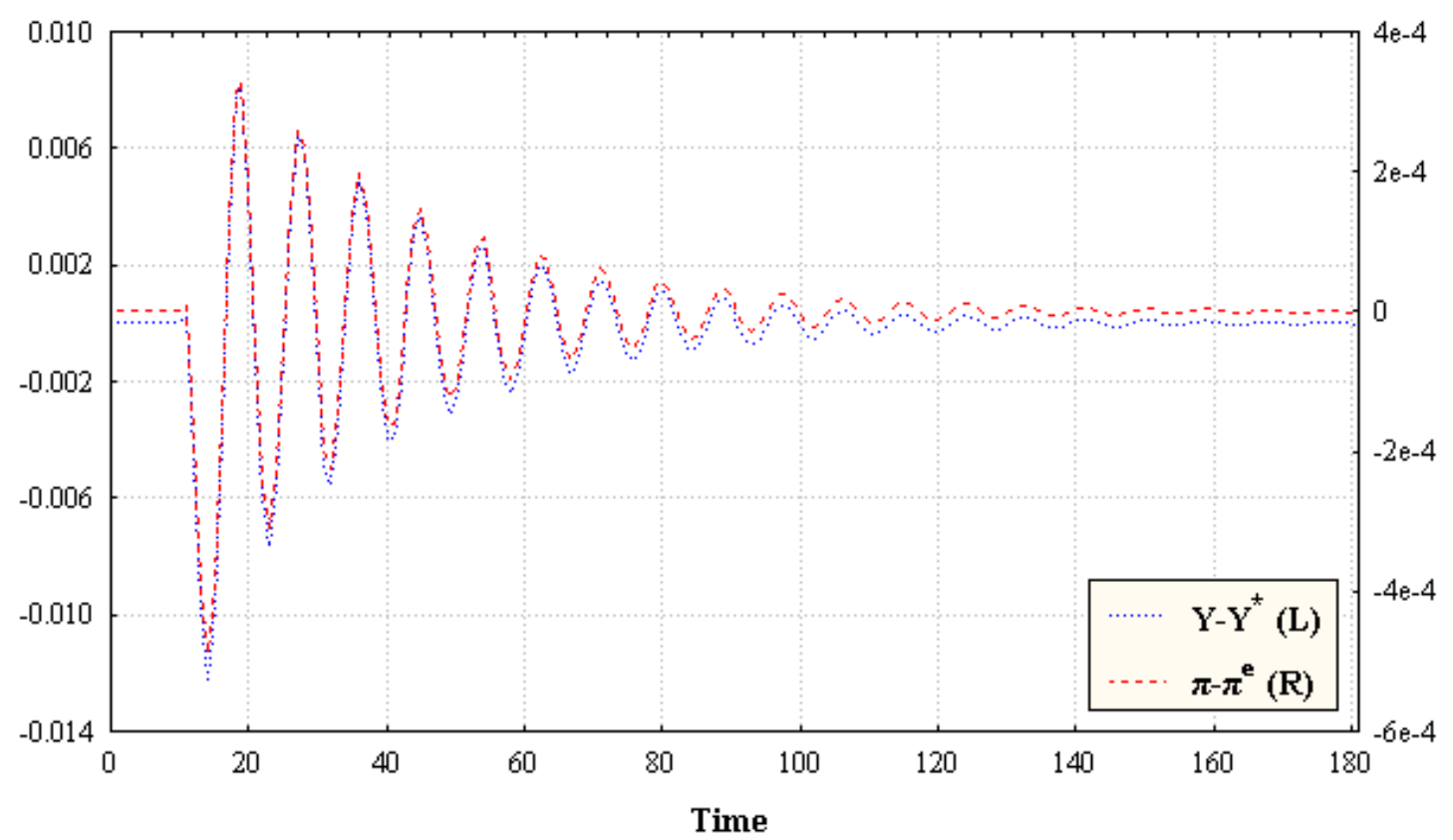


Table 2: Arithmetic evolution of main macroeconomic variables

\begin{tabular}{|c|c|c|c|c|c|c|c|}
\hline $\mathbf{t}$ & $\mathbf{Y}_{\mathbf{t}}$ & $\mathbf{C}_{\mathbf{t}}$ & $\mathbf{I}_{\mathbf{t}}$ & $\boldsymbol{\pi}_{\mathbf{t}}$ & $\boldsymbol{\pi}_{\mathbf{t}}^{\mathbf{e}}$ & $\mathbf{M}_{\mathbf{t}} / \mathbf{P}_{\mathbf{t}}$ & $\mathbf{r}_{\mathbf{t}}$ \\
\hline 0 & 50.03333 & 40.02667 & 0.00667 & 0.04000 & 0.04000 & 10.00000 & -0.02667 \\
10 & 50.03358 & 40.02667 & 0.00667 & 0.04001 & 0.04000 & 9.98990 & -0.00637 \\
11 & 50.02886 & 40.02687 & 0.00174 & 0.03983 & 0.04001 & 9.99170 & -0.0186 \\
20 & 50.03217 & 40.03030 & 0.00162 & 0.03937 & 0.03942 & 9.99626 & -0.01908 \\
40 & 50.02935 & 40.02346 & 0.00565 & 0.03886 & 0.03902 & 10.00142 & -0.03011 \\
60 & 50.03440 & 40.02631 & 0.00783 & 0.03893 & 0.03889 & 10.00069 & -0.02651 \\
80 & 50.03417 & 40.02758 & 0.00634 & 0.03905 & 0.03902 & 9.99949 & -0.02433 \\
100 & 50.03289 & 40.02658 & 0.00606 & 0.03901 & 0.03903 & 9.99992 & -0.02571 \\
120 & 50.03320 & 40.02644 & 0.00651 & 0.03899 & 0.03899 & 10.00015 & -0.02601 \\
140 & 50.03348 & 40.02673 & 0.00649 & 0.03900 & 0.03900 & 9.999999 & -0.02559 \\
160 & 50.03334 & 40.02671 & 0.00638 & 0.03900 & 0.03900 & 9.99996 & -0.02559 \\
180 & 50.03329 & 40.02664 & 0.00640 & 0.03900 & 0.03900 & 10.00001 & -0.02570 \\
200 & 50.03334 & 40.02666 & 0.00643 & 0.03900 & 0.03900 & 10.00001 & -0.02568 \\
\hline
\end{tabular}

The magnitudes of real consumption and real investment remain steady since at period $t=10$ both variables are still determined by the equilibrium values of income and real interest rate. The increase of real income in period $t=$ 10 affects positively the levels of consumption and investments in period $t=11$. In the same period, the level of the latter is affected negatively because of the raise in previous period's real interest rate. As time tends to infinity, the real stock of money returns, as it was expected, to its initial equilibrium value. Moreover, real investment converges to its lower new equilibrium level while real interest rate to its new and higher equilibrium value. It must be noted that the magnitudes of real investments and real interest rate are both converging to their new equilibrium values through oscillations. This is graphically affirmed by figure 4 .

Figure 4: Diachronic evolution of real investments and real interest rate

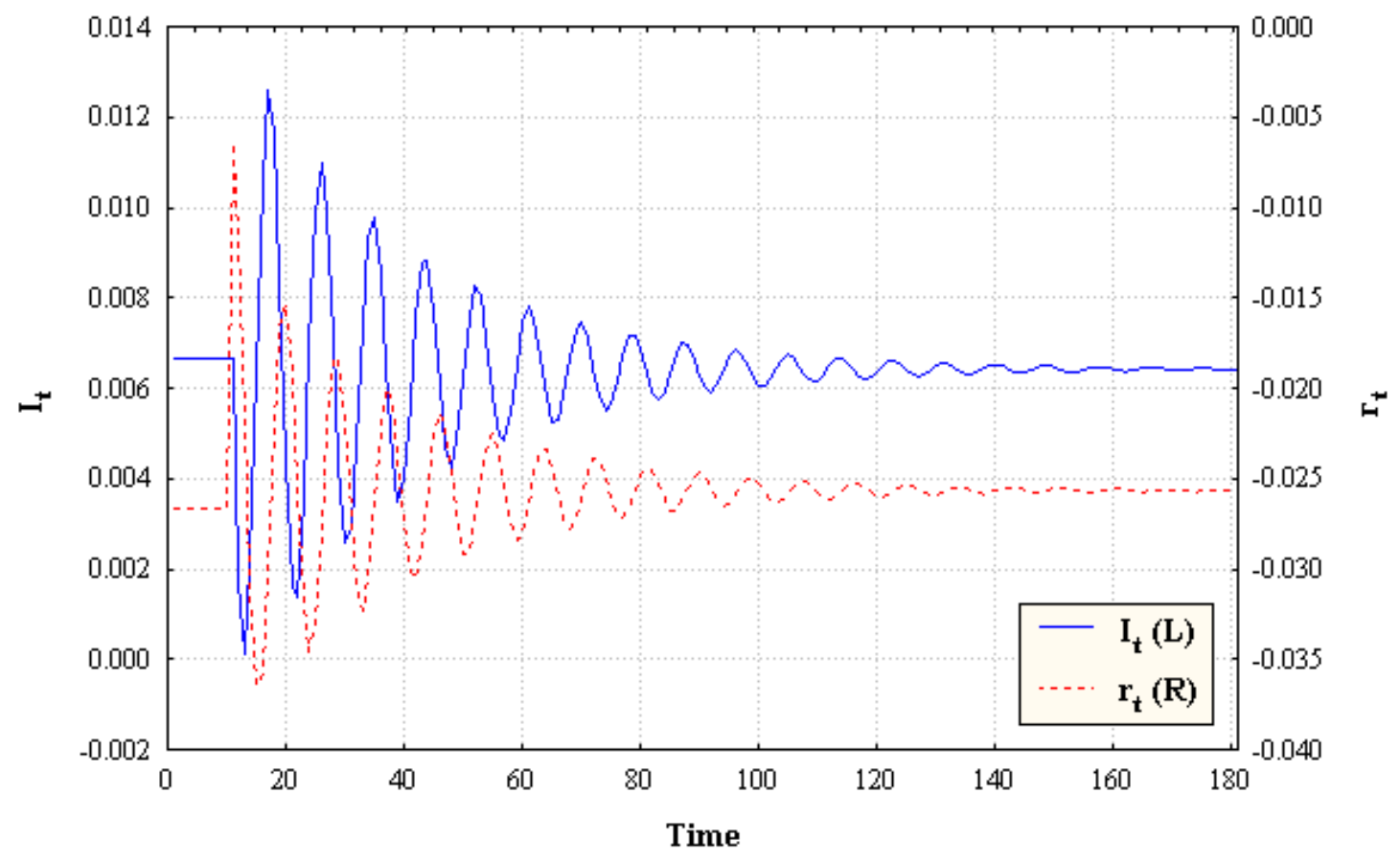


Figure 5: Contemporaneous evolution of $I_{t}, C_{t}-C_{t-1}$ and $r_{t-1}$

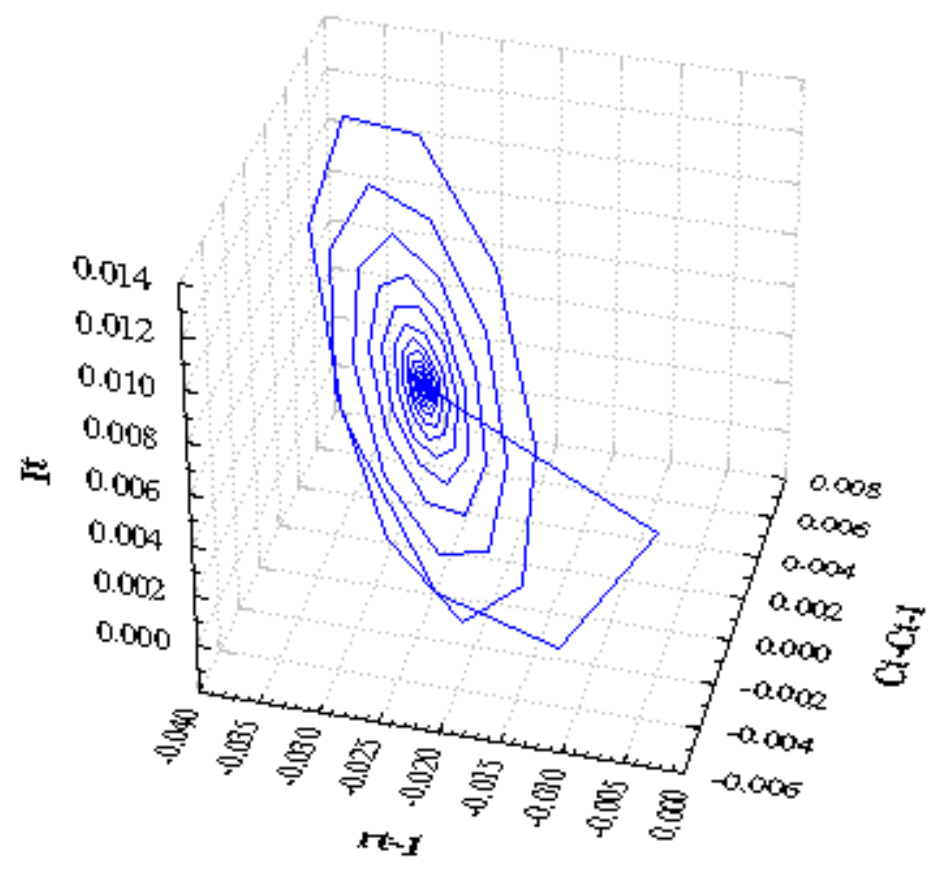

Figure 6: Line plot of real income and real investments

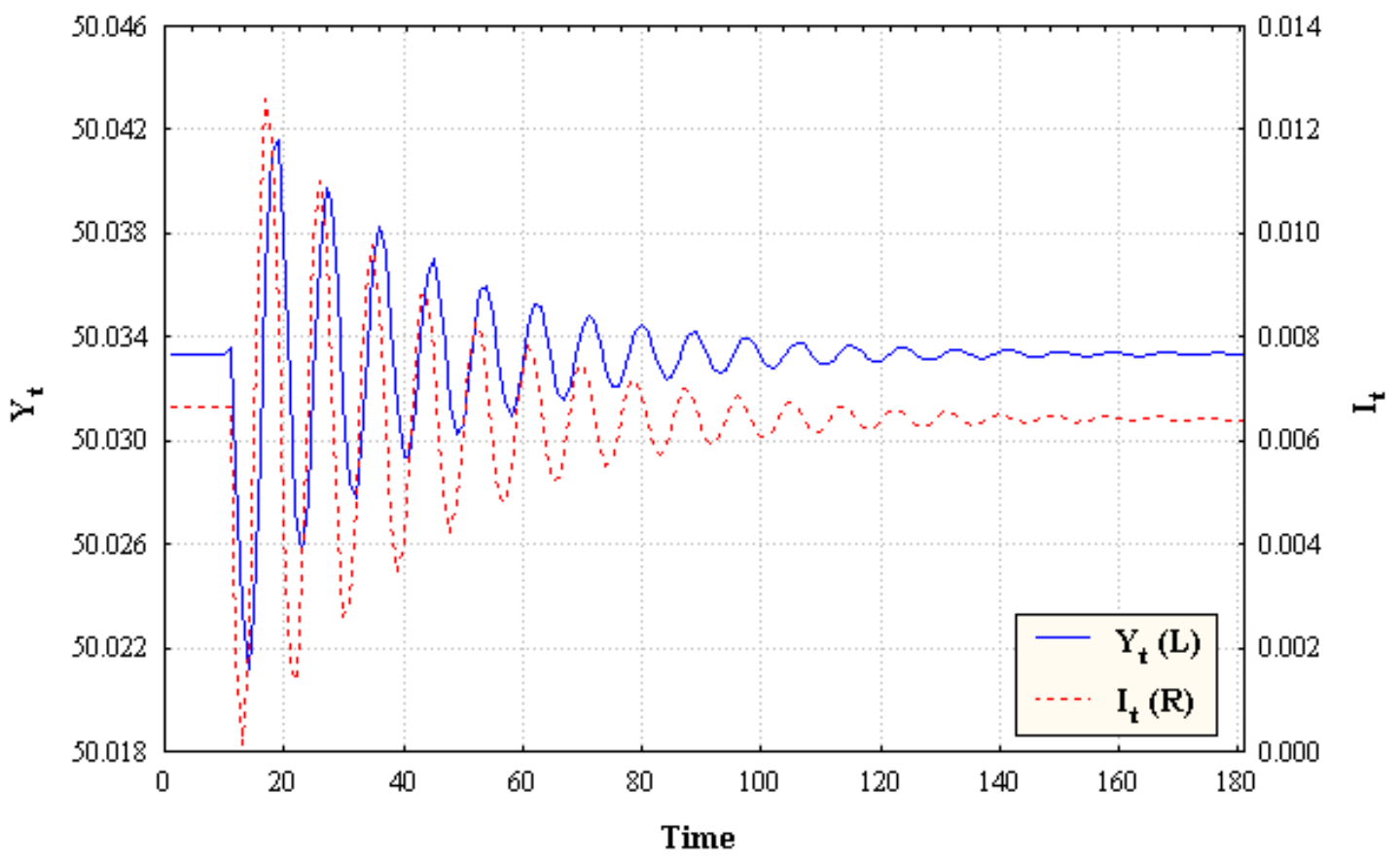


In figure 5 we present the contemporaneous evolution of real investments, previous period's real interest rate and the change of real consumption. According to this figure, it is quite clear the negative relation between the levels of $I_{t}$ and $r_{t-1}$ and the positive relation between the levels of $I_{t}$ and $\Delta C_{t}$. Finally, in figure 6 we compare the movements of real income and real investments and we clearly see the pro-cyclical movement of investments.

\section{CONCLUSIONS}

In the present paper we developed a simple dynamic New Keynesian type model using the multiplier accelerator principle in order to examine the quantitative impact of changes in the level of government expenditures and the growth rate of nominal money supply on the level of several macroeconomic magnitudes. Monetary policy (changes in the growth rate of nominal money supply) is the key policy instrument to achieve inflationary targeting.

In the context of this model, the expected equality between actual and expected inflation on the one hand and real and potential income on the other hand is avowed in the long - run. As a result, fiscal or monetary changes leave the equilibrium value of real income unaffected. However, the presence of real government expenditure $(\bar{G})$ and the growth rate of nominal money supply $(\mathrm{m})$ as constituent elements of the equilibrium value of inflation permit the influence of government and Central Bank on the long - run value of actual and expected inflation. More specifically, a change in $G$ affects positively the equilibrium value of inflation and negatively the equilibrium value of real stock of money. Central Bank could offset, however, these two negative results through appropriate changes in m. As we have seen, the stability of the equilibrium value of real stock of money is achieved, when the value of $m$ is determined according to a relation ensuring the equality between the equilibrium value of inflation and the growth rate $\mathrm{m}$. Thus, monetary policy can have short - run effects on real magnitudes.

\section{SUGGESTIONS FOR FUTURE RESEARCH}

In the present article we specified the rule of determination of growth rate of nominal money supply that is equal to the equilibrium value of inflation. This rule helps the Central Bank to set the inflation target so that the real stock of money will not be affected by changes in government expenditures. A subject for future research could be the determination of the factors that affect the amplitude of oscillation of actual and expected inflation around their equilibrium values. Moreover we could determine the magnitude of these factors for which the amplitude of oscillation is minimized.

\section{REFERENCES}

1. Arestis, P. and Sawyer, M., Can Monetary Policy Affect the Real Economy?, The Levy Institute, Public Policy Brief No 71, 2003.

2. Bernake, B.; Gertler, M., and Gilchirst, S., The Financial Accelerator in a Quantitative Business Cycle Framework, in Taylor and Woodford eds. Handbook of Macroeconomics, Vol. 1, North Holland, 1999.

3. Bernanke, B. S. and Blinder, A. S., Credit, Money and Aggregate Demand, American Economic Review, Vol. 78, No 2, pp. $435 \sim 439,1988$.

4. $\quad$ Bernanke, B. S.; Laubach, T.; Mishkin, F. S., and Posen, A., Inflation Targeting: Lessons from the International Experience, Princeton University Press, N.J., 1999.

5. Bernanke, B. and Mishkin, F. S, Inflation Targeting: A New Framework for Monetary Policy?, Journal of Economic Perspectives, Vol. 11 , No 2, pp. $97 \sim 116,1997$.

6. Barro, R. J., Macroeconomics, $5^{\text {th }}$ edition, The MIT Press, Cambridge, Massachusetts, London, England, 1997.

7. Biederman, D., Permanent Income and Long - Run Stability in the Generalized Multiplier/Accelerator Model, Journal of Macroeconomics, Vol. 15, No 2, pp. $249 \sim 272,1993$.

8. Caff, J. T., A Generalization of the Multiplier - Accelerator Model, The Economic Journal, Vol. 71, No 281, pp. $36 \sim 52,1961$.

9. Cagan, P., The Monetary Dynamics of Hyperinflation, in Friedman M. (eds.), Studies in the Quantity Theory of Money, Chicago University Press, Chicago, pp. 25 117, 1956.

10. Clarida, R.; Gali, J., and Gertler, M., The Science of Monetary Policy: A New Keynesian Perspective, Journal of Economic Literature, Vol. 37, No 4, pp. 1661 1707, December 1999. 
11. Debelle, G. and Fischer, S., How Independent Should a Central Bank Be? in Fuhrer, J. C. (eds.), Goals, Guidelines, and Constraints Facing Monetary Policymakers, Massachusetts: Federal Reserve Bank of Boston, Boston, pp. 195 221, 1994.

12. Dornbusch, R. and Fischer, S., Macroeconomics, $8^{\text {th }}$ edition, McGraw - Hill, N.Y., 1993.

13. Fischer, S., Recent Developments in Macroeconomics, The Economic Journal, Vol. 98, No 391, pp. 294 339, 1988.

14. Gandolfo, G., Economic Dynamics - Study Edition, Springer - Verlag, Berlin, 1997.

15. Hannsgen G., Minsky's Acceleration Channel and the Role of Money, Journal of Post Keynesian Economics, Vol. 27, No 3, pp. $471 \sim 489,2005$.

16. Hicks, J. R., A Contribution to the Theory of Trade Cycle, Oxford University Press, 1950.

17. Karpetis, C., and Varelas, E., The Multiplier - Accelerator Interaction under Constant Monetary Expansion, (in Greek), Piraeus: University of Piraeus edition in honor of Professor T. Skountzos (forthcoming), $2004 \mathrm{a}$.

18. Karpetis, C. and Varelas, E., Monetary Policy, Inflationary Expectations and the Determination of Income in the Context of Samuelson's Business Cycles Model, (in Greek), Political Economy (forthcoming), $2004 \mathrm{~b}$.

19. Kaskarelis, I. A. and Varelas, E. G., Permanent Income and Credit Rationing in the Open Economy Multiplier/Accelerator Model: An Exercise for the Developing Countries Case, Journal of Macroeconomics, Vol. 18, No 3, pp. $531 \sim 549,1996$.

20. Kenkel, J. L., Dynamic Linear Economic Models, Gordon \& Breach Science Publishers, New York, 1974.

21. King, R. G., Will the New Keynesian Macroeconomics Resurrect the IS - LM Model?, The Journal of Economic of Economic Perspectives, Vol. 7, No 1, pp. 67 82, 1993.

22. King, M., Changes in UK Monetary Policy: Rules and Discretion in Practice, Journal of Monetary Policy, Vol. 39, No 1, pp. $81 \sim 97,1997$.

23. Kuttner, K. and Mosser, P., The Monetary Transmission Mechanism: Some Answers and Further Questions, FRBNY Economic Policy Review, 2002.

24. Laidler, D., The Permanent Income Concept in a Macro-Economic Model, Oxford Economic Papers, Vol. 20, No 1, pp. $11 \sim 23,1968$.

25. McCallum, B. T., Monetary Economics - Theory and Policy, Macmillan Publishing Company, New York, 1989.

26. Metzler, L. A., The Nature and Stability of Inventory Cycles, Review of Economics and Statistics, Vol. 23, No 3, pp. $113 \sim 129,1941$.

27. Minsky, H. P., Monetary Systems and Accelerator Models, The American Economic Review, Vol. 47, No 6, pp. $859 \sim 883,1957$.

28. Okun, A., Potential GNP: Its Measurement and Significance, Proceedings of the Business and Economics Statistics Section of the American Statistical Association, 1962.

29. Phelps, E. S., Phillips Curves, Expectations of Inflation and Optimal Unemployment over Time, Economica, Vol. 34, No 135, pp. $254 \sim 281,1967$.

30. Phillips, A.W., The Relation Between Unemployment and the Rate of Change of Money Wage Rates in the United Kingdom, 1861 - 1957, Economica, Vol. 25, No 100, pp. $283 \sim$ 300, 1958.

31. Romer, D., Advanced Macroeconomics, McGraw - Hill, New York, 1996.

32. Samuelson, P. A., Interactions Between the Multiplier Analysis and the Principle of Acceleration, Review of Economics and Statistics, Vol. 21, No 2, pp. $75 \sim 78,1939$.

33. Smithies, A., Economic Fluctuations and Growth, Econometrica, Vol. 25, No 1, pp. $1 \sim 52,1957$.

34. Smith, D. J., Monetary Factors and Multiplier - Accelerator Interaction, Economica, Vol. 30, No 120, pp. $400 \sim 407,1963$.

35. Svensson, L. E. O. and Woodford, M., Implementing Optimal policy Through Inflation-Forecast Targeting, NBER Working Paper Series No. 9747, Massachusetts: National Bureau of Economic Research, Cambridge, 2003.

36. Wright, A. Ll., The Rate of Interest in a Dynamic Model, The Quarterly Journal of Economics, Vol. 72, No 3, pp. $327 \sim 350,1958$. 


\section{NOTES}

